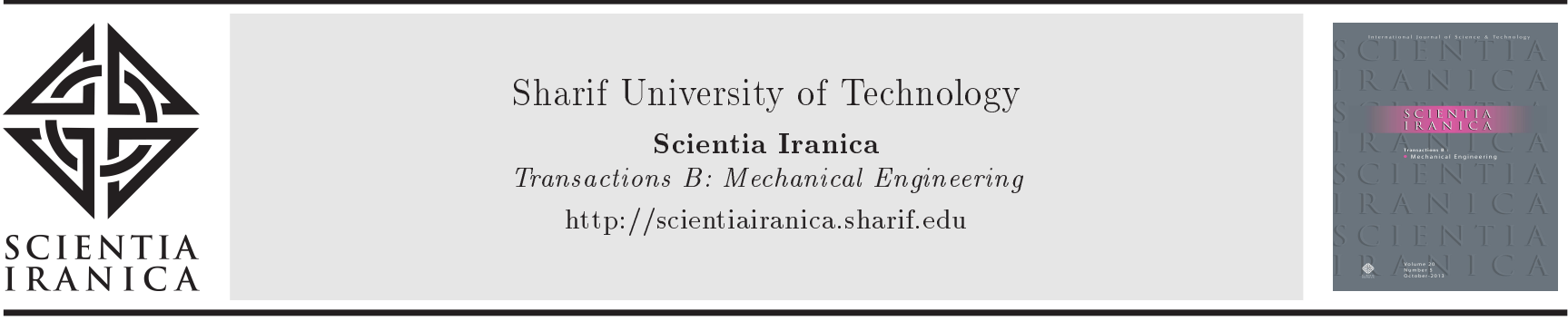

\title{
Analysis of the effect of temperature on the morphology of egg shell calcium oxide catalyst: Catalyst production for biodiesel preparation
}

\author{
T.S. Singh* and T.N. Verma \\ Department of Mechanical Engineering, National Institute of Technology Manipur, Imphal-795004, India.
}

Received 31 December 2018; received in revised form 18 March 2019; accepted 13 July 2019

KEYWORDS
Calcium oxide;
Chicken egg;
Duck egg;
Catalyst.

\section{Introduction}

Alarmed by the increasing pollution created by conventional diesel engines [1], researchers have identified biodiesel production trends and accordingly, proposed allocating more capital investment to searching for a better source of biofuel. Numerous studies have shown that biodiesel could be produced from various sources such as edible oils, non-edible oil, waste fat of fish and animals, alcohols [2], waste tyre and plastics [3,4], waste cooking oils, microalgae [5-12], etc. In the conventional process of biodiesel production, a process

\footnotetext{
*. Corresponding author. Tel.: +919402932585

E-mail addresses: th.subhas143@gmail.comand

th.s.singh@nitmanipur.ac.in (T.S.Singh)

verma.tikks@gmail.com and tikendra.me@nitmanipur.ac.in (T.N. Verma)
}

doi: $10.24200 /$ sci. 2019.52573 .2780 commonly known as transesterification is used to reduce the viscosity and density of the raw biofuel. The process usually involves heat treatment of biofuel with alcohol, preferably ethanol/methanol, in the presence of a catalyst at about 50 to $75^{\circ} \mathrm{C}$ for a certain time period. The process is deemed completed after removing glycerol from the conical flask, purifying the leftover esters, and washing off any alcohol or catalyst. Normally, $\mathrm{KoH}$ or $\mathrm{NaOH}$ was used as a catalyst for the transesterification process. However, in an attempt to reduce costs and minimize the damaging impacts on the environment, an eco-friendly catalyst was developed. Amongst the widely used catalysts, Calcium Oxide $(\mathrm{CaO})$ is highly outstanding. In a search for sourcing and producing $\mathrm{CaO}$ in much cheaper ways, researchers have conducted various experiments to extract $\mathrm{CaO}$ from renewable sources. For instance, a study was conducted on sourcing and producing $\mathrm{CaO}$ from Scallop waste shell which was further used as a catalyst 
for biodiesel production. Another similar trend of synthesized $\mathrm{CaO}$ includes solid ostrich, chicken egg shells, river snail shells, and others used as catalysts, as reported by other studies. These studies have reported that the application of eggshell-based $\mathrm{CaO}$ catalysts had a recognizable methyl ester conversion rate, compared to those using $\mathrm{KoH}$ or $\mathrm{NaOH}$ [13-17]. Researchers have also reported use of homogeneous catalysts such as commercial $\mathrm{KoH}$ for methanolysis of Canola oil using response surface methodology. They obtained a conversion rate of $84.42 \%$, which was in good agreement with the already predicted value of $89.15 \%$ [18]. They also stressed the significance of biofuels (bioethanol) to internal combustion engine research [19]. Many studies regarding the catalysts have suggested that there are various effects of temperature on the morphology and chemical and physical characteristics of the catalyst deemed substances. For instance, a study reported that the surface area of the alumina catalyst was drastically reduced when the temperature reached $1100^{\circ} \mathrm{C}\left(14 \mathrm{~m}^{2} / \mathrm{g}\right)$ from its initial $800^{\circ} \mathrm{C}\left(265 \mathrm{~m}^{2} / \mathrm{g}\right)$ [20]. Preparation of nanocatalyst by the microemulsion method was demonstrated through the use of $\left(\mathrm{H}_{2} \mathrm{O}+\mathrm{H}_{2} \mathrm{PtCl}_{6}\right) / n$ - heptane/Triton $\mathrm{X}$ 100/2-butanol and $\left(\mathrm{HCl}(\mathrm{aq})+\mathrm{H}_{2} \mathrm{PtCl}_{6}\right) / n-h e p-$ tane/Triton $X-100 / 2-b u t a n o l$. The study concluded that the content of $\mathrm{HCl}$ had an important effect on the activity and shape of the nanocatalyst [21]. Excellent yield of catalyst was also reported through the condensation of amines, aldehydes, and unmodified ketones under solvent-free conditions in the presence of $\mathrm{Znl}_{2}$. The study also concluded that the same approach would be inapplicable with chiral catalyst [22].

The possibility of using washed cells of Lactobacillus plantarum PTCC 1058 and Lactobacillus plantarum subsp. Plantarum PTCC1745 as the catalysts used for producing linoleic acid from castor oil was previously reported in a study. The reactions were further optimized and the researchers concluded that Lactobacillus plantarum PTCC 1058 was a better catalyst since it had a higher production yield of $36 \%$ in $121 \mathrm{hr}$ at $15 \%$ (w/v) cell [23]. Use of catalyst through impregnation method for methanation of carbon dioxide was successful. The study showed that conversion of $86.82 \%$ $\mathrm{CO}_{2}$ and $61.94 \% \mathrm{CH}_{4}$ was achieved at a reaction temperature of $200^{\circ} \mathrm{C}$ while using $\mathrm{Ru} / \mathrm{Mn}$ (30:70)$\mathrm{Al}_{2} \mathrm{O}_{3}$ catalyst (calcinated at $1000^{\circ} \mathrm{C}$ ) [24]. On the contrary, researchers have introduced sodium alginate as an effective and renewable biopolymer catalyst [25]. Heterogeneous catalysts such as $\mathrm{MoO}_{3} / \mathrm{CuMoO}_{4}$ were prepared as selective nanoparticle catalysts for epoxidation of olefins. The study revealed higher selectivity and activity of the catalyst during the reaction [26]. Other studies suggested that the catalyst prepared by the addition of aluminium nitrate in the paste of boehmie, $\delta$-alumina, polyethylene glycol 400, and nitric acid as a peptizing agent resulted in an increase in lateral crushing strength by up to $50 \%$ $\left(622 \mathrm{~N} / \mathrm{cm}^{2}\right)$ [27]. Yet, the problem which hinders the applicability of such sophisticated catalysts is the matter of availability and cost. The effectiveness of the catalyst is proportionate to the cost of the catalyst. Hence, many researchers hold the view that the use of easily accessible materials, which are cheap and highly reusable, must be encouraged as catalysts [28]. Nanocatalyst can also be successfully prepared using microemulsion route in hydrogenation reactions [29]. Another study emphasized that addition of $\mathrm{CuO}$ to FAZ-X (fly ash derived zeolite-X) would significantly improve the catalytic activity and reusability of the waste-derived catalyst. Similarly, other researchers proposed the application of environmentally friendly and highly reusable catalysts to carrying out reactions [30-34]. The necessity of this issue is evident since biodiesels have better characteristics in emission during combustion from internal combustion engines [35-39]. Other researchers have emphasized the need to study the effect of temperature on materials which have the capability to act as catalysts [40-47].

Following a close review of the literature and other related researches, the authors did not find a significant correlation between the formation of CaO-based heterogeneous catalyst and the effect of calcination temperature. In many of the reported works, the researchers failed to illustrate the effect of the calcination temperature on the formation of $\mathrm{CaO}$ from egg shells. Hence, they made efforts to bridge the knowledge gap in understanding the effect of the calcination temperature to the formation of $\mathrm{CaO}$ from egg shells. The present study considers two samples, chicken and duck egg shells, which are widely available as waste material, and they are calcinated to form $\mathrm{CaO}$ at different temperatures $\left(700^{\circ} \mathrm{C}, 800^{\circ} \mathrm{C}\right.$, and $\left.900^{\circ} \mathrm{C}\right)$. The calcinated samples were characterized using $\mathrm{X}$ Ray Diffraction (XRD), Fourier- Transform Infrared (FT-IR) spectrometry, Scanning Electron Microscope (SEM), and Energy Dispersive X-ray analysis (EDX).

\section{Material and method}

\subsection{Material collection}

Among the widely consumed poultry products, egg is considered to be a healthy source of protein and other nutrients. Hence, it is pretty easy to collect the leftover egg shells as they are thrown away in large quantity from numerous homes, hotels, and shops. Apart from chicken eggs, duck eggs are also considered to be delicate due to their intense flavour and thus, obtaining duck egg shells is not a problem for researchers. A batch of chicken and duck egg shells (250 gm each) was collected from the National Institute of Technology Manipur, Imphal, India 


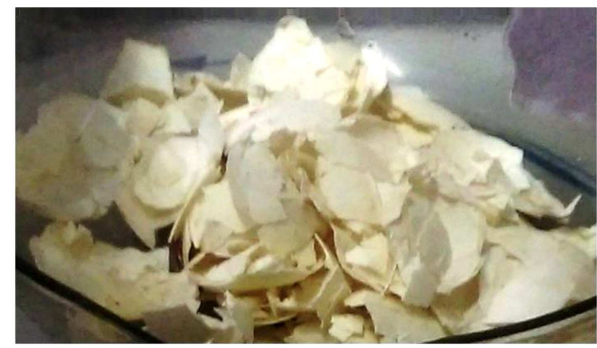

(a) Chicken egg shells

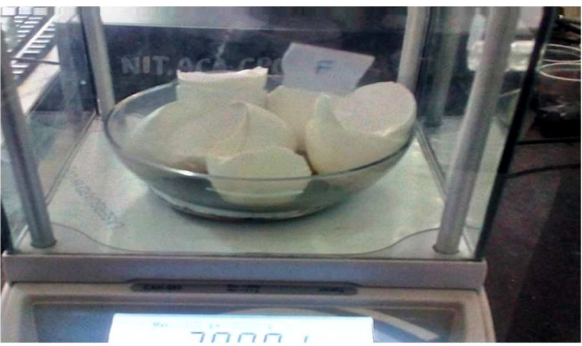

(b) Duck egg shells

Figure 1. Chicken and duck egg shells measured on an electronic scale of accuracy $\pm 0.005 \mathrm{~g}$.

$\left(24.832^{\circ} \mathrm{N} \& 93.914^{\circ} \mathrm{E}, 785 \mathrm{~m}\right.$ above sea level). The collected samples are shown in Figure 1.

\subsection{Preparation of $\mathrm{CaO}$ catalyst}

The egg shells were preheated at $80^{\circ} \mathrm{C}$ in an electric oven for few hours $(2-3 \mathrm{hr})$ to ensure that the samples were fully dried $[13,47]$ of any leftover moisture. Afterward, a mild force was applied to the egg shell samples to coarsely crush them in order to determine the size of $10-20 \mathrm{~mm}$ (approx.) smaller samples. The samples were then weighed using an electronic scale and by using a stainless-steel cup, they were exposed to different temperatures of $700^{\circ} \mathrm{C}, 800^{\circ} \mathrm{C}$, and $900^{\circ} \mathrm{C}$ by an electric muffle furnace for about an hour. After exposure, the samples were cooled inside the insulated electric oven for about 4-5 hr. They were finely crushed using a mortar and then, kept within closed cups for easy storage.

\subsection{Characterization of $\mathrm{CaO}$ catalyst}

For characterization, the $\mathrm{CaO}$ samples were exposed to XRD for recording the diffraction patterns using a Bruker AXS (D8-Advanced) with $1.5406 \AA$ of $\mathrm{Cu}-\mathrm{K} \alpha$ radiation in the $2 \theta$ range of $20^{\circ}$ to $80^{\circ}$. The samples were then exposed to Perkin Elmer (spectrum two) FT-IR spectrometer and the corresponding values were recorded using instrument-equipped Spectrum $10^{\mathrm{TM}}$ software with $\mathrm{LiTaO}_{3}$ detector. The chemical morphology of the samples was studied using Nova NanoSEM (1.0 nm@30 kV resolution, 5x to 1,000,000 x magnification) with Bruker SDD-EDS detector attached to EDX analyzer. The techniques and methodology placed by AOAC (1998) [46] were followed for determining the properties of chicken and duck egg shells.

\section{Results and discussion}

By following the procedures laid down by AOAC (1998) and after performing the experiments five times, the mean values of ash and moisture of the samples were observed to be $4.28 \pm 0.034 \mathrm{~g} / 100 \mathrm{~g}$ and $3.04 \pm 0.028 \mathrm{~g} / 100 \mathrm{~g}$ (chicken egg shells) as well as $5.05 \pm 0.051 \mathrm{~g} / 100 \mathrm{~g}$ and $2.96 \pm 0.021 \mathrm{~g} / 100 \mathrm{~g}$, respectively (duck egg shells). Again, calcium and magnesium contents (dry basis) of the samples were found $65.7 \mathrm{mg} / 100 \mathrm{~g}$ and $61.76 \mathrm{mg} / 100 \mathrm{~g}$ as well as $59.4 \mathrm{mg} / 100 \mathrm{~g}$ and $63.8 \mathrm{mg} / 100 \mathrm{~g}$ for chicken and duck egg shells, respectively.

\subsection{XRD pattern of the samples}

Figure $2 \mathrm{a}$ and $2 \mathrm{~b}$ shows the XRD of the synthesized $\mathrm{CaO}$ from the calcinated chicken and duck egg shells. In both of the cases of chicken and duck egg shells, the diffractions peaks corresponding to (111), (222), and (220) of the face centred cubic phase were observed to be at about $29^{\circ}, 33^{\circ}$, and $47^{\circ}$, respectively, at all temperatures. Less intense peaks were also noticed at around $35^{\circ}, 39^{\circ}$, and $53^{\circ}$ in the diffraction patterns. This is in agreement with the findings of other researchers $[6,13,17]$. It can be noted that the exposure of the samples to higher temperatures in both of chicken and duck egg shells resulted in rapid decline of calcium ions and homogenous nucleation of calcium, thus allowing the formation of smaller size $\mathrm{CaO}$. This result is consistent with the reported work of other researchers $[40-42,45,47]$.

\subsection{FT-IR spectroscopy of the samples}

Similar observations to the findings of the XRD were found in FT-IR results. The IR spectra for the calcinated $\mathrm{CaO}$ samples of chicken and duck egg shells are shown in Figures $3 \mathrm{a}$ and $3 \mathrm{~b}$, respectively. The figure shows the infra-red spectra at $400-2000 \mathrm{~cm}^{-1}$ wavenumbers. The exhibition bands of $1474 \mathrm{~cm}^{-1}$ and $869 \mathrm{~cm}^{-1}$ define the asymmetric stretching of $\mathrm{C}=\mathrm{O}$ for carbonaceous group, which may be explained by the chemisorption of $\mathrm{CO}_{2}$ from the atmosphere on the surface of the synthesized $\mathrm{CaO}$. The extra stretching of Ca-O at about $406 \mathrm{~cm}^{-1}$ and $407 \mathrm{~cm}^{-1}$ displays the formation of $\mathrm{CaOs}$ during the calcination process at all of the exposed temperatures. This phenomenon is explained by the vibrations of $\mathrm{Ca}-\mathrm{O}$ lattice of pure $\mathrm{CaO}$ [43]. The findings of the present study are consistent with the reported work of other researchers [44]. The absorption was reduced with an increase in calcination temperature. Although there were few changes in the spectra of chicken egg shells and variations in the calcination temperature, higher fluctuations in the absorption of the duck egg shell $\mathrm{CaO}$ 
Egg shells @ 800
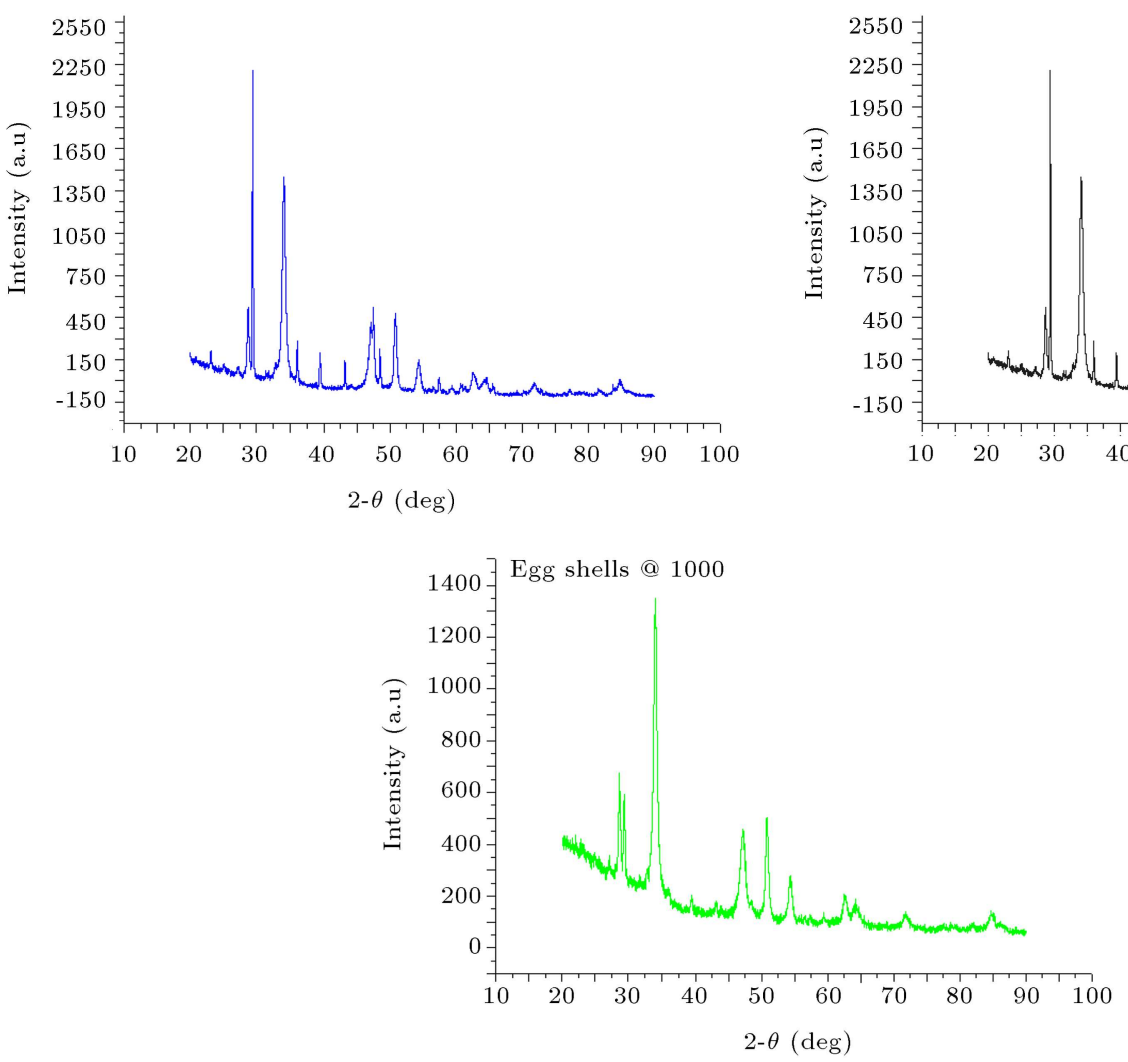

Figure 2a. X-Ray Diffraction (XRD) findings of the calcinated chicken shell CaO.
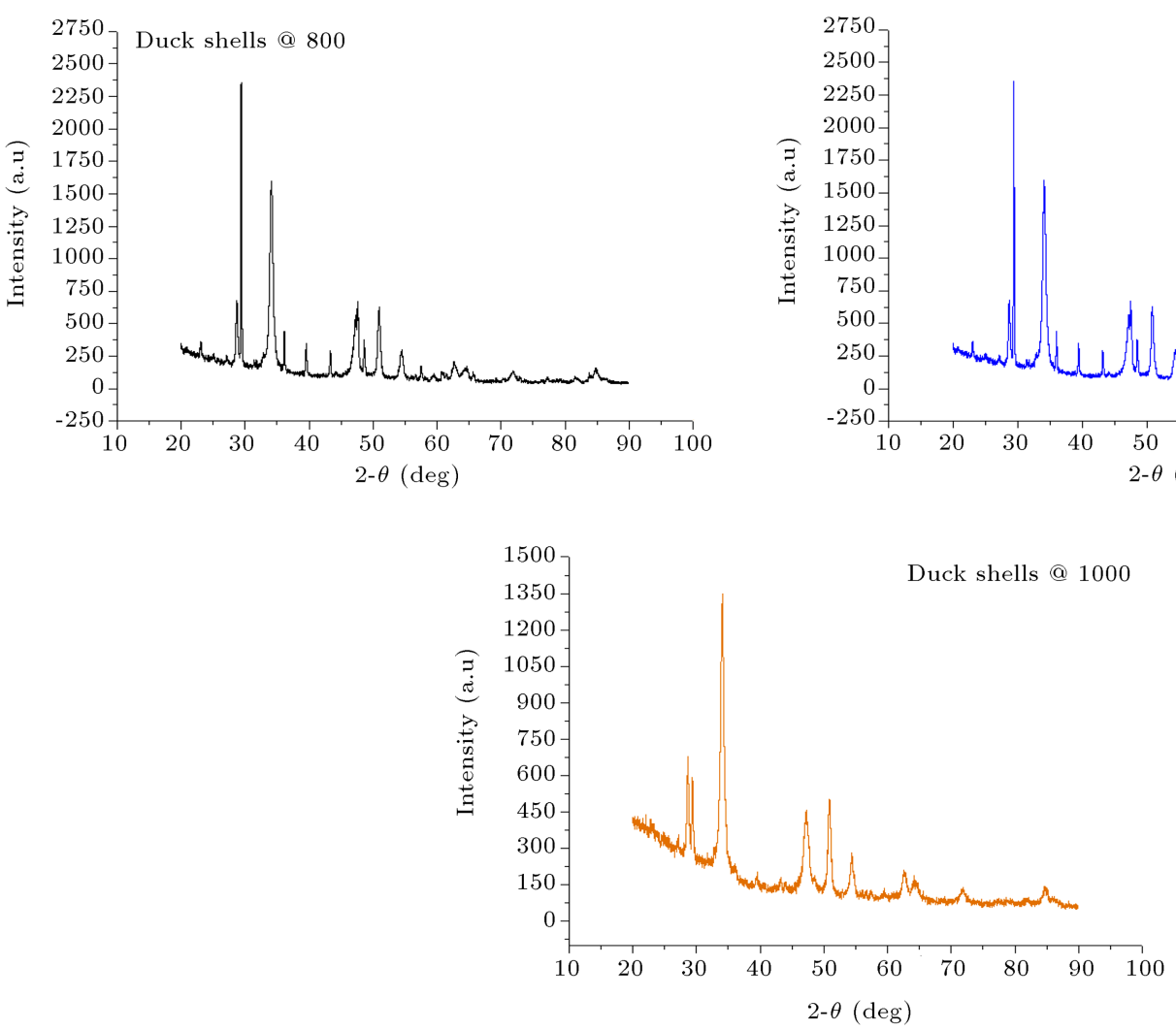

Figure 2b. X-Ray Diffraction (XRD) findings of the calcinated duck shell CaO. 


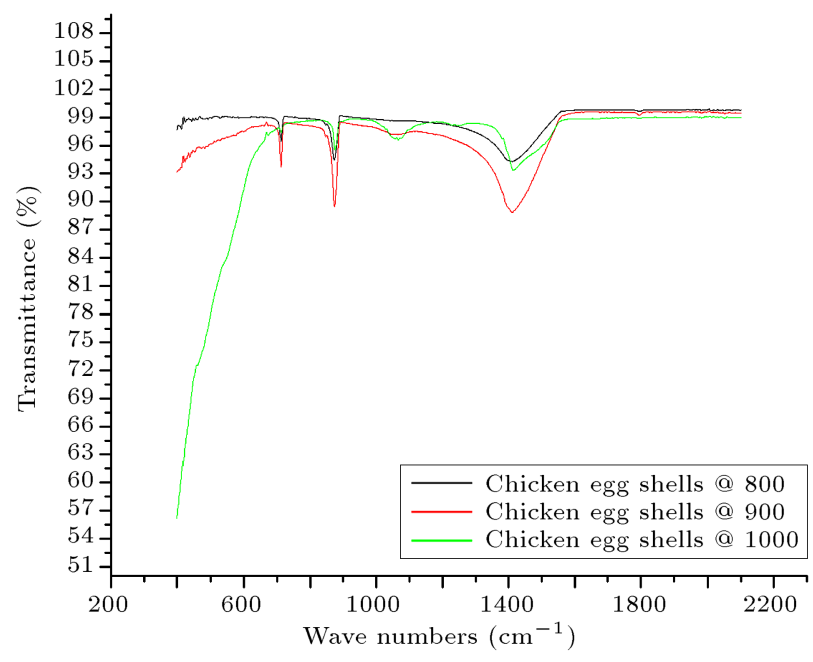

Figure 3a. Fourier-Transform Infrared (FT-IR) findings of the calcinated chicken shell $\mathrm{CaO}$.

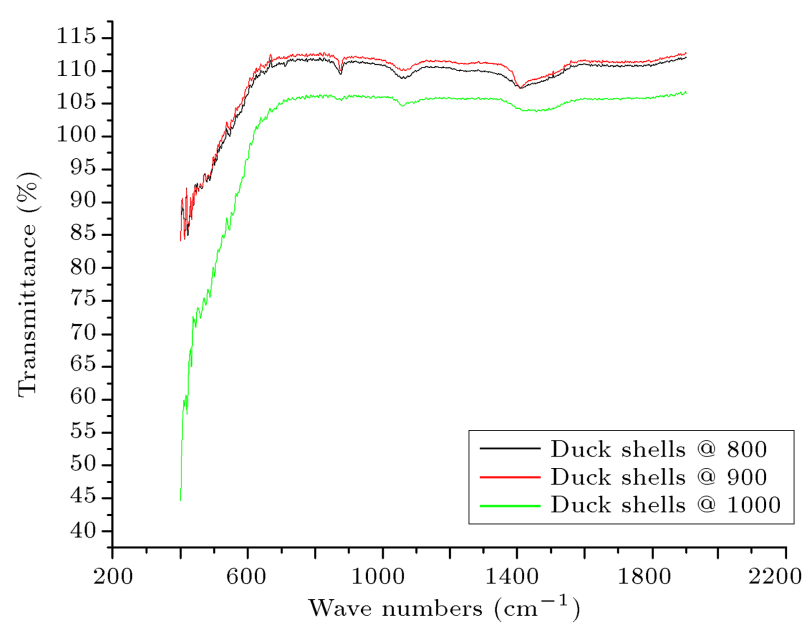

Figure 3b. Fourier Transform Infrared (FT-IR) findings of the calcinated duck shell $\mathrm{CaO}$.

were observed. The transmittance of the duck egg shell $\mathrm{CaO}$ was reduced with an increase in the calcination temperature $\left(1000^{\circ} \mathrm{C}\right)$, although fewer changes at tem- peratures $800^{\circ} \mathrm{C}$ and $900^{\circ} \mathrm{C}$ were observed.

\subsection{Scanning electron microscopy of the samples}

The morphology of the synthesized CaO (50000 x magnification) from chicken and duck egg shells after their exposure to different temperatures of (a) $800^{\circ} \mathrm{C}$, (b) $900^{\circ} \mathrm{C}$, and (c) $1000^{\circ} \mathrm{C}$ is shown in Figures 4 and 5 , respectively. The figure shows that the grains of $\mathrm{CaO}$ are asymmetrical and are of varying sizes. This might have been caused by the exposure of the samples to varying temperatures. Due to the exposure to higher temperatures, the grains were seen to be agglomerated with tremendous permeable nature. Therefore, an EDX analysis was conducted to show the elemental composition of the samples. Figure 6(a) and (b) shows EDX of the synthesized $\mathrm{CaO}$ from chicken and duck egg shells, respectively.

\subsection{EDX characterization of the samples}

From the EDX results presented in Figure 6, the composition of $\mathrm{CaO}$ in its elemental state comprising calcium $(\mathrm{Ca})$, oxide $(\mathrm{O})$ and naturally occurring substance, carbon (C) can be observed. In the case of chicken egg shells with $\mathrm{CaO}$ shown in Figure 6(a), the sample exposed to $900^{\circ} \mathrm{C}$ had more $\mathrm{C}$ and $\mathrm{O}$ with less $\mathrm{Ca}$, while at $800^{\circ} \mathrm{C}$, the composition of $\mathrm{C}$ in the sample decreased and there was an increase in $\mathrm{Ca}$ and $\mathrm{O}$. At $1000^{\circ} \mathrm{C}$, the carbon content of the sample suddenly escalated, while the amount of $\mathrm{O}$ and $\mathrm{Ca}$ was almost similar to $\mathrm{CaO}$ at $800^{\circ} \mathrm{C}$. Thus, the temperature of $800^{\circ} \mathrm{C}$ was found to be better in terms of $\mathrm{Ca}$ and $\mathrm{O}$ composition with lower $\mathrm{C}$ content. Increase in the temperature from $800^{\circ} \mathrm{C}$ to $900^{\circ} \mathrm{C}$ and then to $1000^{\circ} \mathrm{C}$ was unfavorable as it increased the content of carbon in the sample, which is evidently seen in the figure.

Similarly, in the case of duck egg shell with $\mathrm{CaO}$, shown in Figure 6(b), the $\mathrm{CaO}$ obtained at $800^{\circ} \mathrm{C}$ was found to be quite suitable as it contained a large quantity of $\mathrm{Ca}$ and $\mathrm{O}$ with less $\mathrm{C}$. Increase in the

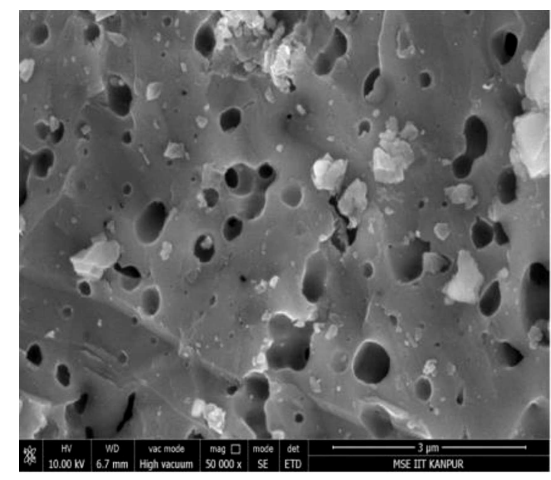

(a)

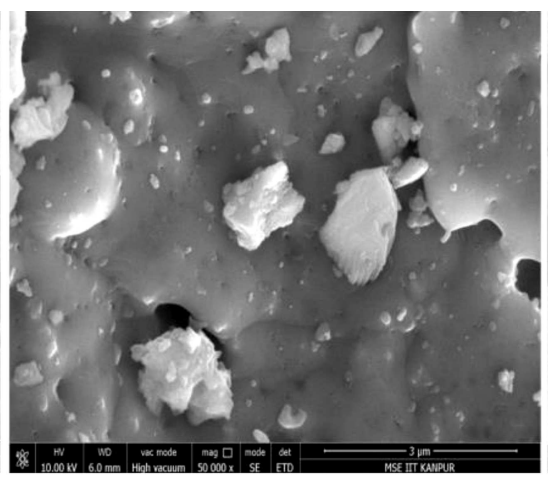

(b)

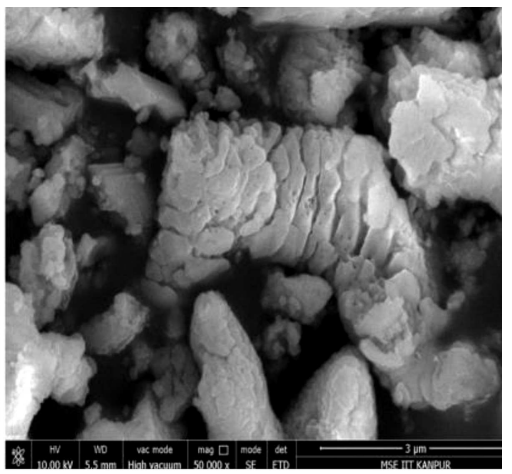

(c)

Figure 4. Scanning Electron Microscope (SEM) image showing the surface morphology of chicken egg shell with CaO at (a) $800^{\circ} \mathrm{C}$, (b) $900^{\circ} \mathrm{C}$, and (c) $1000^{\circ} \mathrm{C}$. 


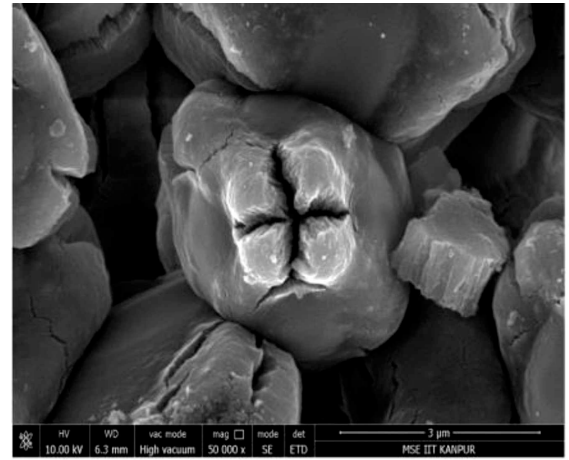

(a)

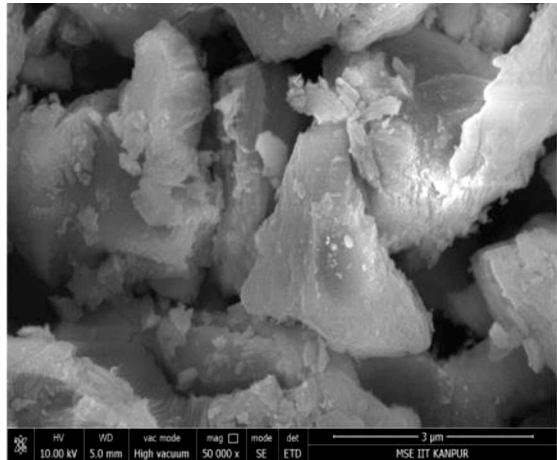

(b)

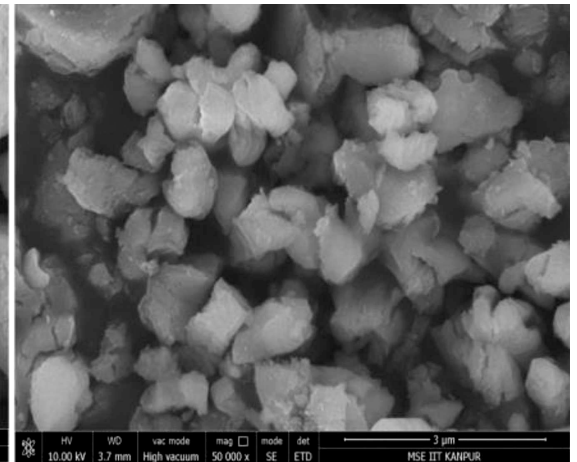

(c)

Figure 5. Scanning Electron Microscope (SEM) image showing the surface morphology of duck egg shell with CaO at (a) $800^{\circ} \mathrm{C}$, (b) $900^{\circ} \mathrm{C}$, and (c) $1000^{\circ} \mathrm{C}$.
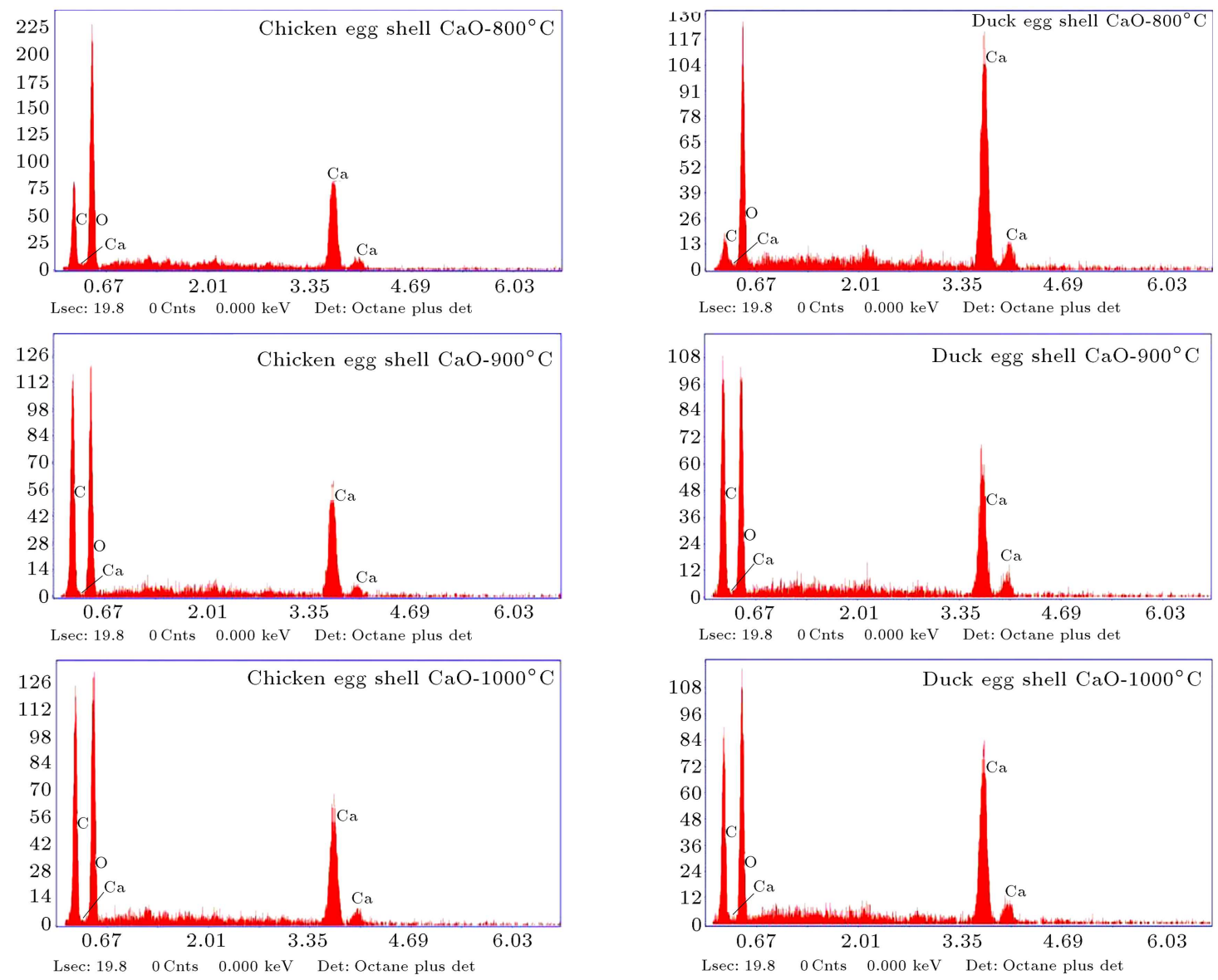

(a)

(b)

Figure 6. Energy Dispersive X-ray analysis (EDX) of (a) chicken egg shell with $\mathrm{CaO}$ and (b) duck egg shell with CaO.

calcination temperature had a negative effect on the distribution of $\mathrm{Ca}$ and $\mathrm{O}$ in the samples. Increasing the calcination temperature to $900^{\circ} \mathrm{C}$ was found to lower the $\mathrm{Ca}$ distribution in the sample, while an extensive increase in $\mathrm{C}$ was observed. Further increase in the temperature to $1000^{\circ} \mathrm{C}$ resulted in a slight decrease in $\mathrm{C}$ distribution in the sample with slight $\mathrm{Ca}$ enhancement.

\section{Conclusion}

A parametric study of the effect of temperature on the morphology of $\mathrm{CaO}$ synthesized from chicken egg shells and duck egg shells at varying calcination temperatures of $800^{\circ} \mathrm{C}, 900^{\circ} \mathrm{C}$, and $1000^{\circ} \mathrm{C}$ was carried out. The samples were prepared and the following observations were found: 
- The ash and moisture content of chicken and duck egg shells were $4.28 \pm 0.034 \mathrm{~g} / 100 \mathrm{~g}$ and $3.04 \pm$ $0.028 \mathrm{~g} / 100 \mathrm{~g}$ as well as $5.05 \pm 0.051 \mathrm{~g} / 100 \mathrm{~g}$ and $2.96 \pm 0.021 \mathrm{~g} / 100 \mathrm{~g}$, respectively;

- The X-ray diffraction patterns of all the samples at $29^{\circ}, 33^{\circ}$, and $47^{\circ}$ showed the formation of $\mathrm{CaO}$ at all temperatures corresponding to the (111), (200), and (220) of the face centered cubic phase;

- Fourier Transform Infrared (FI-IR) spectrometry showed extra stretching of $\mathrm{Ca}-\mathrm{O}$ at about $406 \mathrm{~cm}^{-1}$ and $407 \mathrm{~cm}^{-1}$ at all exposed temperatures. Exhibition bands of $1474 \mathrm{~cm}^{-1}$ and $869 \mathrm{~cm}^{-1}$ defined the asymmetric stretching of $\mathrm{C}=\mathrm{O}$ for the carbonaceous group;

- Grains were observed to be asymmetrical and of varying sizes. Energy Depersive X-Ray analysis (EDX) showed that greater amount of Calcium (Ca) and Oxygen $(\mathrm{O})$ was detected at $800^{\circ} \mathrm{C}$ for both chicken and duck egg shells.

It can be concluded that $800^{\circ} \mathrm{C}$ is quite suitable and favorable as it contains acceptable amounts of $\mathrm{Ca}$, $\mathrm{O}$ and less $\mathrm{C}$ in both of the $\mathrm{CaO}$ samples obtained from chicken and duck egg shells. The authors hope that the present findings provide a reference study for the researchers working in the area of catalyst synthesis using egg shells for biodiesel production.

\section{Acknowledgement}

The authors sincerely thank Department of Chemistry, NIT Manipur, Imphal, India for their extensive support in providing XRD \& FTIR analysis along with other facility for measuring various properties. The authors also acknowledge SEM with EDX facility provided by IIT Kanpur.

\section{References}

1. Singh, T.S., Verma, T.N., Nashine, P., and Shijagurumayum, C. "BS-III diesel vehicles in imphal, India: An emission perspective", In: Sharma N., Agarwal A., Eastwood P., Gupta T., Singh A. Eds. Air Pollution and Control Energy, Environment, and Sustainability, Springer, Singapore (2018). https://doi.org/10.1007/978-981-10-7185-0-5

2. Rajak, U. and Verma, T.N. "Effect of emission from ethylic biodiesel of edible and non-edible vegetable oil, animal fats, waste oil and alcohol in CI engine", Energy Convers Manag, 166, pp. 704-718 (2018). DOI: 10.1016/j.enconman.2018.04.070

3. Hurdogan, E., Ozalp, C., Kara, O., et al. "Experimental investigation on performance and emission characteristics of waste tire pyrolysis oildiesel blends in a diesel engine", Int. J Hydrogen Energy, 2(36), pp. 23373-23378 (2017). DOI: 10.1016/j.ijhydene.2016.12.126
4. Devaraj, J., Robinson, Y., and Ganapathi, P. "Experimental investigation of performance, emission and combustion characteristics of waste plastic pyrolysis oil blended with diethyl ether used as fuel for diesel engine", Energy, 85, pp. 304-309 (2015). DOI: 10.1016/j.energy.2015.03.075

5. Adewale, P., Vithanage, L.N., and Christopher, L. "Optimization of enzyme-catalyzed biodiesel production from crude tall oil using Taguchi method", Energy Convers. Manag, 154, pp. 81-91 (2017).

6. Singh, T.S. and Verma, T.N. "Impact of tri-fuel on compression ignition engine emissions: blends of waste frying oil-alcohol-diesel", In: Agarwal A., Gautam A., Sharma N., Singh A., Eds. Methanol and the Alternate Fuel Economy, Energy, Environment, and Sustainability, Springer, Singapore (2019). https://doi.org/10.1007/978-981-13-3287-6-7

7. Garcia, M.C.C., Sanchez, M.D.M., Miron, A.S., et al. "A process for biodiesel production involving the heterotrophic fermentation of Chlorella protothecoides with glycerol as the carbon source", Appl Energy, 103, pp. 341-349 (2013). DOI: 10.1016/j.apenergy.2012.09.054

8. Rajak, U. and Verma, T.N. "Spirulina microalgae biodiesel-A novel renewable alternative energy source for compression ignition engine", J Clean Prod, 201, pp. 343-357 (2018). Doi: 10.1016/j.jclepro.2018.08.057

9. Vassilev, S.V. and Vassileva, C.G. "Composition, properties and challenges of algae biomass for biofuel application: An overview", Fuel, 181, pp. 1-33 (2016). DOI: $10.1016 /$ j.fuel.2016.04.106

10. Rajak, U., Nashine, P., and Verma, T.N. "Assessment of diesel engine performance using spirulina microalgae biodiesel", Energy, 166, pp. 1025-1036 (2018).

11. Salam, S. and Verma, T.N. "Appending empirical modelling to numerical solution for behaviour characterisation of microalgae biodiesel", Energy Convers. Manag., 180, pp. 496-510 (2019).

12. Rajak, U., Nashine, P., and Verma, T.N. "A comparative analysis of engine characteristics from various biodiesels: Numerical study", Energy Convers. Manag., 180, pp. 904-923 (2019).

13. Buasri, A., Worawanitchaphong, P., and Trongyong, S. "Utilization of scallop waste shell for biodiesel production from palm oil-optimization using taguchi method", Procedia-Soc. Behav. Sci., 8, pp. 216-221 (2014). DOI: $10.1016 /$ j.apcbee.2014.03.030

14. Tan, Y.H., Abdullah, M.O., Nolasco-hipolito, C., et al. "Application of RSM and Taguchi methods for optimizing the transesterification of waste cooking oil catalyzed by solid ostrich and chicken-eggshell derived CaO”, Renew. Energy, 114(B), pp. 437-447 (2017).

15. Latchubugata, C.S., Kondapaneni, R.V., Patluri, K.K., et al. "Kinetics and optimization studies using response surface methodology in biodiesel production using Heterogeneous catalyst", Chem. Eng. Res. Des., 135, pp. 129-139 (2018). 
16. Niju, S., Begum, K.M.M.S., and Anantharaman, N. "Modification of egg shell and its application in biodiesel production", J. Saudi Chem. Soc., 18(5), pp. 702-706 (2014).

17. Kaewdaeng, S., Sintuya, P., and Nirunsin, R. "Biodiesel production using calcium oxide from river snail shell ash as catalyst", Energy Procedia, 138, pp. 937-942 (2017).

18. Vahabzadeh, F., Hajar, M., and Shokrollahzadeh, S. "Empirical modeling of the enzymatic methanolysis of canola oil", Sci. Iran., 17(1), pp. 97-105 (2010).

19. Ghahremani, A., Jafari, M., Ahari, M., et al. "Experimental and theoretical investigation on spray characteristics of bio-ethanol blends using a direct injection system", Sci. Iran., 24(1), pp. 237-248 (2017).

20. Komeili, S., Takht Ravanchi, M., and Taeb, A. "Influence of calcination parameters on the properties of alumina as a catalyst support", Sci. Iran., 23(3), pp. 1128-1135 (2016).

21. Salabat, A. and Keshavarz, A. "Effect of $\mathrm{HCl}$ on the structure and catalytic activity of $\mathrm{Pt} / \mathrm{Al}_{2} \mathrm{O}_{3}$ nanocatalyst prepared in microemulsion system", Sci. Iran, 26(3), pp. 1925-1930 (2019).

22. Azizi, N., Ebrahimi, F., and Saidi, M.R. "Highly efficient one-pot three-component mannich reaction under solvent-free conditions", Organic Letters, 16(2), pp. 94-98 (2009).

23. Kouchak Yazdi, Z., Alemzadeh, I., and Vossoughi, M. "Comparison and optimization of conjugated linoleic acid production by Lactobacillus plantarum and Lactobacillus plantarum subsp. Plantarum", Sci. Iran., 24(3), pp. 1272-1280 (2017).

24. Abu Bakar, W.A.W., Ali, R., Sulaiman, N., et al. "Manganese oxide doped noble metals supported catalyst for carbon dioxide methanation reaction", Sci. Iran, Trans. C-Chemistry Chem. Eng., 17(2), pp. 115123 (2010).

25. Daemi, H., Rad, R.R., Adib, M., et al. "Sodium alginate: A renewable and very effective biopolymer catalyst for the synthesis of 3,4-dihydropyrimidin2(1H)-ones", Sci. Iran., 21(6), pp. 2076-2081 (2014).

26. Najai, M., Abbasi, A., and Masteri-Farahani, M. "Preparation of MoO3/CuMoO4 nanoparticles as selective catalyst for olefin epoxidation", Sci. Iran., 24(3), pp. 1203-1208 (2017).

27. Zarezadeh-Mehrizi, M., Afshar Ebrahimi, A., and Rahimi, A. "Preparation of extruded alumina with suitable crushing strength and good stability", Sci. Iran., 25(3C), pp. 1434-1439 (2018).

28. Ghomi, G.S., Alavi, H.S., and Ziarati, A. "A multi-component reaction for direct access to 4,40(phenylmethylene)bis(1H-pyrazol-5-ol)-3-carboxylates using nano-NiZr4(PO4)6 in water", Sci. Iran., 25(6), pp. 3288-3294 (2018).

29. Salabat, A., Mirhoseini, F., and Abdoli, Kh. "A microemulsion route to fabrication of mono and bimetallic $\mathrm{Cu} / \mathrm{Zn} / \gamma-\mathrm{Al} 2 \mathrm{O} 3$ nanocatalysts for hydrogenation reaction", Sci. Iran., 25(3), pp. 1364-1370 (2018).
30. Subramanian, E. and Subbulekshmi, N.L. "Enhanced heterogeneous wet hydrogen peroxide catalytic oxidation performance of fly ash-derived zeolite by $\mathrm{CuO}$ incorporation", Sci. Iran., 24(3), pp. 1189-1202 (2017).

31. Mosaddegh, E. and Hassankhani, A. "Mn (III) complex catalyzed a green synthesis of 2-amino- $4 \mathrm{H}-$ chromen-5(6H)-ones in basic aqueous solution at ambient temperature", Sci. Iran., 21(6), pp. 2082-2086 (2014).

32. Rezaee Nezhad, E., Abbasi, Z., and Sajjadifar, S. "Fe2+supported on hydroxyapatite-core-shell- $\gamma$ Fe2O3 nanoparticles: As a novel, efficient and magnetically-recoverable catalyst for the synthesis of dihydropyrimidinones derivatives", Sci. Iran., 22(3), pp. 903-910 (2015).

33. Heidarizadeh, F., Zahedi, M.M., and Nourizad, S. "An efficient and improved method in the synthesis of 14alkyl and 14-aryl-14H-dibenzo [a,j]xanthenes using 1butyl-3-methyl imidazolium phosphotungstate as catalyst under solvent free conditions", Sci. Iran. Trans. C-Chemistry Chem. Eng., 22, pp. 919-925 (2015).

34. Neyestani-Naeeni, E. and Naimi-Jamal, M.R. "Nanoporous MCM-41-SO3H as an efficient catalyst for chalcones and dibenzylidene alkanones synthesis via solvent-free aldol condensation reaction", Sci. Iran., 22(6), pp. 2282-2289 (2015).

35. Rajak, U., Nashine, P., Singh, T.S., et al. "Numerical Investigation of combustion, performance and emission characteristics of various biofuels", Energy Convers. Manag., 156, pp. 235-252 (2018).

36. Rajak, U., Nashine, P., and Verma, T.N. "Comparative assessment of the emission characteristics of first, second and third generation biodiesel as fuel in a diesel engine", J. Thermal Engg (2018) (In press).

37. Rajak, U., Nashine, P., and Verma, T.N. "Effect of fuel injection pressure in a diesel engine using Microalgaediesel emulsion", Int. J. Engg. Adv. Tech., 8(3), pp. 225-232 (2019).

38. Rajak, U. and Verma, T.N. "Numerical investigation on cylindrical combustion chamber for methane-air fuel", Int. J. Theo. App. Research Mech Engg, 6(1), pp. 148-150 (2017).

39. Kumar, R. and Verma, T.N. "Performance characteristics of a spark ignited variable compression ratio engine at erratic loads", Int. J. App. Phy, 3, pp. 9-13 (2018).

40. Singh, T.S. and Verma, T.N. "An assessment study of using Turel Kongreng (river mussels) as a source of heterogeneous catalyst for biofuel production", Biocatalysis and Agricultural Biotechnology, 20, 101185 (2019).

41. Fayaz, A.M., Balaji, K., Kalaichelvan, P.T., et al. "Fungal based synthesis of silver nanoparticles-An effect of temperature on the size of particles", Colloids Surf., 74 (B), pp. 123-126 (2009).

42. Liu, H, Zhang, H., Wang, J., et al. "Effect of temperature on the size of biosynthesized silver nanoparticle: Deep insight into microscopic kinetics analysis", Arab. J. Chem., 13(1), pp. 1011-1019 (2020). 
43. Zaki, M.I., Knözinger, H., Tesche, B., et al. "Influence of phosphonation and phosphation on surface acidbase and morphological properties of $\mathrm{CaO}$ as investigated by in situ FTIR spectroscopy and electron microscopy", J. Colloid Interface Sc., 303, pp. 9-17 (2006).

44. Pandit, P.R. and Fulekar, M.H. "Egg shell waste as heterogeneous nanocatalyst for biodiesel production: Optimized by response surface methodology", J. Environ. Manage., 198, pp. 319-329 (2017).

45. Adeyeye, E.I. "Comparative study on the characteristics of egg shells of some bird species", Bull. Chem. Soc. Ethiop., 23(2), pp. 159-166 (2009).

46. AOAC, Official Methods of Analysis, 16th Ed. Association of official analytical chemists, Gaithersburg, MD (1998).

47. Singh, T.S. and Verma, T.N. "Taguchi design approach for extraction of methyl ester from waste cooking oil using synthesized $\mathrm{CaO}$ as heterogeneous catalyst: Response surface methodology optimization", Energy Convers. Manag., 182, pp. 383-397 (2019).

\section{Biographies}

Thokchom Subhaschandra Singh is a Lecturer and a PhD candidate at the Department of Mechanical Engineering, National Institute of Technology Manipur, Imphal, India. He holds BE degree in Mechanical Engineering with Distinction \& ME degree in Thermal Engineering with Distinction from Anna University,
Chennai, India. His areas of interest include internal combustion engines, biofuels, alternative fuels, renewable energy, heat transfer, emissions, environmental pollution and control, etc. He has published papers in various reputed journals/books like Energy Conversion and Management, Renewable Energy, Applied Thermal Engineering, Biocatalysis \& Agricultural Biotechnology, Springer book series, etc.

Tikendra Nath Verma is an Assistant Professor at the Department of Mechanical Engineering, National Institute of Technology Manipur, Imphal, India. He received his BE degree in Mechanical Engineering by securing first division from Pt. R.S.S.U. Raipur, India. He obtained his Master's degree in Thermal Engineering from Maulana Azad National Institute of Technology Bhopal, India. He has obtained his PhD degree in the area of "Numerical Simulation of Contaminant Control in Intensive Care Unit of Hospitals" from National Institute of Technology Raipur, India. His present areas of interest include computational fluid dynamics, heat and mass transfer, solar energy, renewable energy, and alternative fuels in internal combustion engines. He has published papers in various reputed journals/books like Energy Conversion and Management, Renewable Energy, Applied Thermal Engineering, Journal of Cleaner Production, Thermal Science and Engineering progress, Biocatalysis \& Agricultural Biotechnology, Springer book series, etc. 